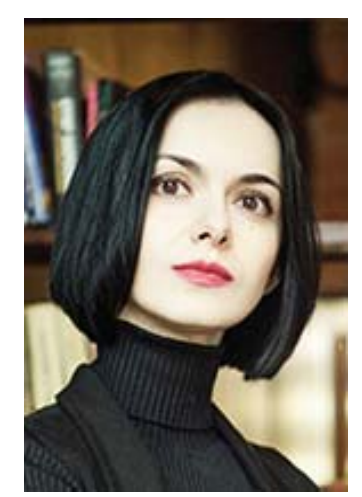

З.В. Галазова

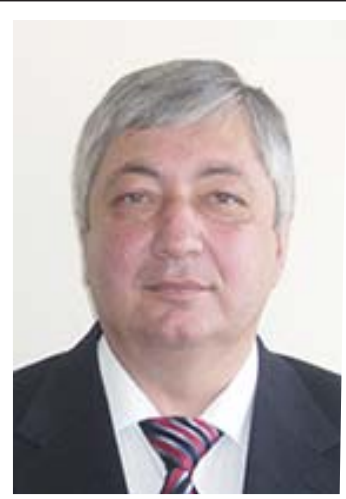

С.А. Макиев
Посредством права государство должно реагировать на меняющиеся общественные отношения. Наблюдаемая в последние годы эволюция гражданско-правовых институтов и правоотношений, разрозненная судебная практика применения законодательства свидетельствовала о необходимости адаптации Гражданского кодекса РФ к новым правилам гражданского оборота.

В целях отражения в ГК РФ опыта его применения и толкования судом, а также сближения положений ГК РФ с правилами регулирования соответствующих отношений в праве Европейского союза, Указом Президента Российской Федерации от 18 июля 2008 г. № 1108 «О совершенствовании Гражданского кодекса Российской Федерации» Совету при Президенте Российской Федерации по кодификации и совершенствованию гражданского законодательства и Исследовательскому центру частного права при Президенте Российской Федерации до 1 июня 2009 г. поручено разработать концепцию развития гражданского законодательства Российской Федерации, а также предложения о мерах по ее реализации, предусмотрев подготовку в 2009-2010 годах проектов федеральных законов о внесении изменений в Гражданский кодекс Российской Федерации.

На основании Указа № 1108 Советом разработана и одобрена Концепция развития гражданского законодательства и последующие проекты фредеральных законов, которыми поэтапно вносились существенные изменения в ГК РФ, во многом повлиявшие на устоявшееся видение гражданскоправовых понятий и институтов. Новшества коснулись и предмета гражданского права.

Обновленный ГК РФ впервые официально включил корпоративные отношения в систему отношений, регулируемых гражданским законодательством, олицетворив тем самым победу научной мысли на пути к норме права.

Совершенно очевидно, что ученые-цивилисты
Удк 347.1.

DOI 10.23671/VNC.2020.1.56947

\title{
О ПРЕДМЕТЕ ГРАЖДАНСКОГО ПРАВА
}

\author{
3.В. Галазова*, С.А. Макиев **
}

Аннотация. В статье рассматриваются актуальные проблемы определения предмета гражданского права. Авторы анализируют понятие и признаки корпоративных отношений, входящих в предмет гражданского права.

Ключевые слова: Концепция развития гражданского законодательства РФ, гражданское право, корпоративные отношения.

стимулируют государственную политику в сфере гражданского законодательства и основные направления его совершенствования, анализируют практику применения ГК РФ, фрормируют законодательную инициативу.

Вспомним, что и в состав Совета по кодификации гражданского законодательства при Президенте РФ входят такие современные цивилисты, как Е.А. Суханов, А.В. Габов, В.М. Жуйков, Г.К. Толстой, А.Л. Маковский и другие.

О корпоративных отношениях, как об отношениях, входящих в предмет гражданского права, одним из первых заявил Д.В. Ломакин, ныне доктор юридических наук, профессор кафедры гражданского права МГУ им. М.В. Ломоносова.

Д.В. Ломакин посвятил обе свои диссертации изучению корпоративных отношений. В 2009 году он защитил докторскую диссертацию на тему «Корпоративные правоотношения как составная часть системы гражданско-правовых отношений». Д.В. Ломакин также отмечал, что ГК РФ не содержит исчерпывающего перечня общественных отношений, регулируемых нормами гражданского права, поэтому любое правоотношение, обладающее всеми характеристиками гражданского правоотношения, должно быть признано гражданским [1].

Следует сказать, что научное сообщество нелегко приняло идеи легального определения корпоративных отношений как области предмета гражданского права, несмотря на то, что фрактически ГК РФ регулировал эти отношения и отсутствие в нем определения этих отношений и места в системе гражданского права не лишало их гражданско-правового характера.

Предмет гражданского права никогда не рассматривался учеными как нечто абсолютное, его содержание всегда носило высокодискуссионный характер, и современной его модификации предшествовали труды таких цивилистов, как С.Н. Братусь, А.В. Венедиктов, Д.М. Генкин, О.С. Иоффре,

* Галазова Залина Викторовна - к. ю. н., доцент кафредры гражданского права и процесса ФГБОУ ВО «Северо-Осетинский государственный университет им. К.Л. Хетагурова»(gala1983@mail.ru).

** Макиев Сослан Александрович - к. ю. н., доцент, заведующий кафедрой гражданского права и процесса ФГБОУ ВО «Северо-Осетинский государственный университет им. К.Л. Хетагурова». 
К.Д. Кавелин, О.А. Красавчиков, Д.И. Мейер, С.А. Муромцев, К.П. Победоносцев, И.А. Покровский, Е.А. Суханов, Г.К. Толстой, Г.Ф. Шершеневич и др.

Итак, сегодня в систему отношений, регулируемых гражданским законодательством, включены корпоративные отношения, под которыми законодатель определил отношения, связанные с участием в корпоративных организациях или с управлением ими. Такая законодательная инициатива породила новую дискуссию в кругах ведущих ученых.

Профрессор Г.К. Толстой в своей статье «О концепции развития гражданского законодательства» в материалах IV Ежегодных научных чтений памяти профрессора С.Н. Братуся 2009 г. [2] отмечает, что предложение о включении корпоративных отношений в предмет гражданского права не вызывает возражений. Однако необходимо определить природу этих отношений, их место в ряду других отношений, входящих в предмет гражданского права, круг участников этих правоотношений, какое влияние корпоративные отношения и решения их участников оказывают как на них самих, так и на третьих лиц.

Иной точки зрения придерживается С.А. Синицын, считая, что законодательная формулировка, определяющая предмет регулирования корпоративных правоотношений через критерий связи, является крайне неопределенной и неточной в своем содержании, порождающей в толковании нормы права широту и вариативные интерпретации, что отнюдь не является достоинством действующего закона, показателем высокого уровня культуры правотворчества [3]. По мнению ученого, корпоративные отношения не являются синонимом отношений по членству.

Взгляды на природу корпоративных отношений можно разделить на несколько концепций:

- корпоративные отношения как имущественные отношения участия, а неимущественные отношения имеют вспомогательный характер (Д.В. Ломакин);

- корпоративные отношения как обязательственные отношения между учредителями (участниками) и корпорацией (Концепция развития гражданского законодательства);

- корпоративные отношения не являются ни вещными, ни обязательственными, а представляют особую группу отношений, регулируемых гражданским правом (О.В. Гутников);

- корпоративные отношения как организационно-имущественные (П.В. Степанов, А.А. Зурабян) [4].

В современных учебниках по гражданскому праву корпоративные правоотношения также определяются как собирательная категория, объединя- ющая имущественные и организационные правоотношения [5].

В.А. Лаптев считает, что законодатель закрепил корпоративные отношения, наряду с вещными и обязательственными отношениями [6].

Следует согласиться с О.В. Гутниковым и В.А. Лаптевым, что корпоративные правоотношения являются самостоятельным видом гражданскоправовых отношений.

На наш взгляд, каждая доктринальная позиция, объясняющая природу корпоративных отношений, имеет право на существование, поскольку эклектично раскрывает их различные стороны, объединяя в одно целое.

При этом видится излишним наделять корпоративные отношения определением «организационных», подменяя им общее понятие «управление», поскольку любое нормативное регулирование сводится к организации общественных отношений.

Предметная область гражданского права определяется рамками имущественных и неимущественных отношений, основанных на триаде: равенство, автономия воли и имущественная самостоятельность участников.

Модификация корпоративных отношений участия (членства) и управления входит в предмет гражданского права постольку, поскольку вписывается в рамки указанной области и содержит в себе все сущностные характеристики гражданских правоотношений.

По своему значению корпоративные правоотношения участия являются первичными, а отношения управления - вторичными, направленными на обеспечение формирования и реализацию воли корпорации через аккумуляцию воли участников.

Дискуссионным является вопрос соотношения управленческих корпоративных отношений с гражданским правом. Однако представляется очевидным отсутствие тождества управления в понимании административно-правовом с внутренним управлением субъектом права. Управление корпорацией в широком смысле то же, что процесс фрормирования воли и принятия решения физическим лицом, необходимый для участия в гражданских правоотношениях.

Управление корпорацией представляет сложную внутреннюю систему взаимоотношений, конечной целью которого является формирование воли юридического лица как субъекта права, способного обеспечить баланс интересов его участников.

Включение корпоративных отношений в число гражданско-правовых представляется обоснованным, а продолжающиеся споры об их месте и характере - свидетельство верного пути в поиске идеальных научных определений. 


\title{
ЛИТЕРАТУРА
}

1. Гражданское право: Учебник. В 2 m. / Под ред. Б.М. Гонгало. Т. 1. 3-е изд. перераб. и доп. - М.: Cmamym, 2018. С использованием СПС «КонсультантПлюс».

2. Зурабян А.A. Корпоративные отношения как вид гражданских правоотношений: авторефр. дисс. ... к. ю. н. - М., 2007. C. 9.

3. Лаптев В.А. Корпоративное право: правовая организация корпоративных систем: монография. - М.: Проспект, 2019. 384 c.

4. Ломакин Д.В. Корпоративные правоотношения: общая теория и практика ее применения в хозяйственных обществах. - M., Cmamym, 2008. С. 98-99.

5. Проблемы совершенствования гражданского законода- тельства Aspects of perfection of the civil legislation: мameриалы IV Ежегодных научных чтений памяти профрессора C.Н. Братуся (Москва, 28 октября 2009 г.) / Ин-т законодательства и сравнительного правоведения при Правительстве Российской Федерации; [редкол.: В.М. Жуйков (отв. ред.) и др.]. - Москва: Юриспруденция, 2010. 366 с.

6. Синицын С.А. Корпоративные правоотношения: содержание и особенности регулирования. // Журнал российского права. 2015. № 6 (222). С. 52-67.

7. Степанов П.В. Корпоративные отношения в коммерческих организациях как составная часть предмета гражданского права Дисс. .. к. ю. н. - М., 1999. С. 9.

\author{
ON THE SUBJECT OF CIVIL LAW \\ Z.V. Galazova*, S.A. Makiev** \\ *PhD, Associate Professor. North Ossetian State University after K. L. Khetagurov (gala1983@mail.ru). \\ ${ }^{* *}$ PhD, Associate Professor. North Ossetian State University after K. L. Khetagurov.
}

Abstract. The article discusses the current problems of determining the subject of civil law. The authors analyze the concept and features of corporate relations belonging to the subject of civil law.

Keywords: The Concept of evolution of the Russian Federation civil legislation, civil law, corporate relations.

\section{REFERENCES}

1. Grazhdanskoe pravo: Uchebnik. V 2 t. Pod red. B.M. Gongalo. T. 1. 3-e izd. pererab. i dop. - M.: Statut, 2018. $S$ ispol'zovaniem SPS «Konsul'tantPlyus».

2. Zurabyan A.A. Korporativnye otnosheniya kak vid grazhdanskikh pravootnosheniy. avtoref. diss. ... k.yu.n. M., 2007. S. 9.

3. Laptev V.A. Korporativnoe pravo: pravovaya organizatsiya korporativnykh sistem: monografiya. - M.: Prospekt, 2019. $384 \mathrm{~s}$.

4. Lomakin D.V. Korporativnye pravootnosheniya: obshchaya teoriya $i$ praktika ee primeneniya $v$ khozyaystvennykh obshchestvakh. - M.: Statut. 2008. S.98-99.

5. Problemy sovershenstvovaniya grazhdanskogo zakonodatel'stva Aspects of perfection of the civil legislation: materialy IV Ezhegodnykh nauchnykh chteniy pamyati professora S. N. Bratusya (Moskva, 28 oktyabrya 2009 g.) / In-t zakonodatel'stva i sravnitel'nogo pravovedeniya pri Pravitel'stve Rossiyskoy Federatsii; [redkol.: V.M. Zhuykov (otv. red.) i dr.]. - Moskva: Yurisprudentsiya, 2010. 366 s.

6. Sinitsyn S.A. Korporativnye pravootnosheniya: soderzhanie i osobennosti regulirovaniya // Zhurnal rossiyskogo prava, 2015. № 6 (222). S. 52-67.

7. Stepanov P.V. Korporativnye otnosheniya $v$ kommercheskikh organizatsiyakh kak sostavnaya chast' predmeta grazhdanskogo prava Diss. .. k.yu.n. - M., 1999. S. 9.

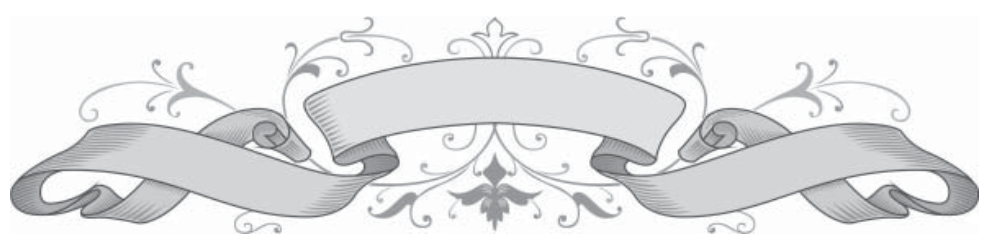

